\title{
Gender equity in early childhood picture books: a cross-cultural study of frequently read picture books in early childhood classrooms in Australia and the United States
}

\author{
Helen $\operatorname{Adam}^{1}$ (D) Laurie J. Harper ${ }^{1,2}$
}

Received: 12 March 2021 / Accepted: 18 October 2021 / Published online: 2 December 2021

(c) The Author(s) 2021

\begin{abstract}
Children's picture books contribute to children's development of gender identity and can impact aspirations and expectations of roles in families and society. However, the world represented in children's books reflects predominantly middle class, heterosexual, male heroes and characters. This paper reports on a cross-cultural study investigating gender representation in frequently read picture books across eight early learning centres in the United States and Australia. Forty-four educators working with 271 children participated. Data were collected from book audits and observations. Unique to this study is the presentation of a new data analysis instrument, Harper's Framework of Gender Stereotypes Contained in Children's Literature. The majority of the books shared by educators in this study promoted traditional, binary and stereotypical viewpoints of gender and gender roles. These findings are concerning as the evidence shows that gender development is a critical part of the earliest and most important learning experience of young children and a requirement of educational policies rooted in the United Nations Convention on the Rights of the Child.
\end{abstract}

Keywords Early childhood · Gender stereotypes · Gender identity · Diversity · Children's literature

Helen Adam

h.adam@ecu.edu.au

Laurie J. Harper

laurie.harper@ecu.edu.au

1 Edith Cowan University, 2 Bradford St, Mt Lawley, WA 6050, Australia

2 Present Address: 46 Wright Lane, Jamestown, RI 02835, USA 


\section{Introduction}

Educators and education systems worldwide aim to educate children to become successful, contributing members of society. To achieve this, children need to experience affirmation of their identities and respect and understanding for those who may be different to themselves (Derman-Sparks \& Edwards, 2010). This vision incorporates the human rights of a child as described in the United Nations Convention on the Rights of the Child (UN CRC) (Office of the High Commissioner for Human Rights, 1989), which embraces the right to an identity, to be free from discrimination, to express opinions and to actively participate in the community and larger society regardless of gender or ethnicity. These basic rights of gender equity, cultural diversity and education for all are echoed in the mission statement of UNESCO $(1945 ; 2009)$ and reflected in educational laws and policies in both Australia and the United States (Australian Children's Education and Care Quality Authority [ACECQA], 2012; Stromquist, 2013).

Consideration of diversity which, in its broadest sense includes gender, race, ethnicity, ability and disability within a range of geographic and socio-economic contexts, is recognised as an important component of quality early childhood education and care (ECEC) across the international early years' landscape (ACECQA, 2012; Adam et al., 2017; Stromquist, 2013)). The extent to which educators accommodate issues of diversity can have implications for the future educational and social success of children (Sylva et al., 2006).

An understanding of the diverse nature of families and communities, including the representation of children of different genders, gender identities, races and abilities can take place through sharing and engaging children in diverse literature (Boutte et al., 2008). Literature can be a powerful means of presenting differing viewpoints and giving voice to those from marginalised gender, cultural and other minority groups (Temple et al., 1998). Thus, literature is a tool that can either promote or disrupt perceptions and viewpoints relating to gender, gender identity, race, ethnicity, ability, disability and social background for children (Boutte et al., 2008; Mendoza \& Reese, 2001). As such, the authors acknowledge all forms of diversity are important and worthy of investigation. However, this article reports on a cross-cultural study exploring gender and gender identity in children's literature.

From a very young age, children are exposed to gender stereotypes through advertising, media and pop culture (Fine, 2010; Saltmarsh, 2009). Gender messages are reinforced by consumer products (Freeman, 2007; Grau \& Zotos, 2016) and media images of provocative, yet passive women and professional, confident and competent men (Grau \& Zotos, 2016; McNair et al., 2001). The classroom materials and literature teachers select to share with young children reflect the beliefs and values a society has about identity, ethnicity and gender equity (Caldwell \& Wilbraham, 2018; Chick et al., 2002; Diekman \& Murnen, 2004; Gee $\&$ Gee, 2005; Jackson, 2007). Through the presentation of socially sanctioned behaviours, both explicit and implicit, children's picture books provide present and future images and models of children (Crisp \& Knezek, 2010; Diekman \& 
Murnen, 2004). Moreover, “characters portrayed in children's literature mold a child's conception of socially accepted roles and values, and indicate how males and females are supposed to act" (Kortenhaus \& Demarest, 1993, p. 220). Of further concern, the affirmation or even representation of children and families which include gender or sexual identities outside of the traditional heteronormative understandings, are most often absent in children's books (Crisp et al., 2016; Daly, 2017; Kelly, 2012; Sullivan \& Urraro, 2017). This absence "can be particularly problematic for children who may be questioning their sexuality or who already identify with diverse sexualities, as a lack of direct engagement with this subject-matter perpetuates its marginalized positioning" (Gillett-Swan \& van Leent, 2019).

Even educators' unconscious attitudes, practices and expectations of boys and girls in class may negatively impact self-confidence (Ebach et al., 2009), reinforce gender stereotypes (de Groot Kim, 2011; Kelly, 2012) and affect girls' and boys' motivation, participation and learning outcomes (United Nations Educational, Scientific and Cultural Organization's [UNESCO], 2016). These unconscious attitudes can impact teachers' selection of children's books, with the outcome that books selected for use with young children may reflect the attitudes towards gender held by the teachers themselves (Ebach, et. al., 2009). Yet sadly, evidence from the last 30 years suggests a longstanding problem with gender representation in children's books (Crisp \& Hiller, 2011a, b; Crisp \& Knezek, 2010; Ferguson, 2019; Hamilton et. al, 2006; Nilsen, 1971, 1978; Tsao, 2008; Weitzman et al., 1972).

Research over many years is clear about the negative impact of sexism and gender stereotypes on children's development; it limits potential growth and development, impacts self-esteem and shapes interpersonal and intrapersonal relationships (Estola, 2011; McCabe et al., 2011; Narahara, 1998). Depictions of gender in children's literature can shape development, influence career aspirations, frame attitudes about future roles in society and impact personality characteristics (Caldwell \& Wilbraham, 2018; Hamilton et al., 2006; Peterson \& Lach, 1990). Furthermore, gender bias in picturebooks and gendered instructional materials strengthens children's biases (McCabe et al., 2011; Poarch \& Monk-Turner, 2001; Rawson \& McCool, 2014;); gives boys a sense of entitlement (Tognoli et al., 1994); lowers girls' self-esteem and occupational aspirations (Caldwell \& Wilbraham, 2018) and teaches children that girls are of less value than boys (Poarch \& Monk-Turner, 2001; Rawson \& McCool, 2014; Weitzam, Eifler,). A 2016 report by the United Nations Educational, Scientific and Cultural Organization's (UNESCO) Global Education Monitoring Report, (2016), found persistent gender bias in textbooks saps girls' motivation, self-esteem and participation in school, thus, undermining their education and limiting career expectations.

All children should have access to authentic and accurate representations of role models related to their gender and cultural backgrounds in order to develop a positive sense of identity and belonging (Adam, 2019, 2021; Adam et al., 2017, 2019; Adam \& Barratt-Pugh, 2020; Derman-Sparks \& Edwards, 2010; Gollnick \& Chinn, 2006; Morgan, 2009). For young children, books play a significant role in transmitting societal values and an important role in their social and academic development (Adam, 2021; Adam et al., 2017, 2019; Adam \& Barratt-Pugh, 2020). High quality 
children's literature provides characters and events with which children can identify and through which they can consider their own actions, beliefs and emotions (Adam, 2021; Adam et al., 2017, 2019; Adam \& Barratt-Pugh, 2020; Davies, 1989; Mendoza \& Reese, 2001; O’Neill, 2010). The characters, conflicts and resolutions contained in the plot of a story offer opportunities for children to further construct their views of self, others and the world. However, gender role stereotyping in the content, language and illustrations of many children's books is pervasive (McCabe et al., 2011), thus, potentially transmitting and reinforcing gender stereotypes and expectations to children.

\section{Gender bias in children's books}

Early studies of gender bias in children's literature from 1938 through the 1970s in Caldecott Medal $^{1}$ winners consistently found under-representation of female characters with males outnumbering females by as much as 5:1. Further, these studies consistently found gender- typed character roles with males portrayed as active, aggressive, directive, persistent, rescuers and mostly outdoors while females were portrayed as passive, emotional, imitative, nurturers, rescued and mostly indoors (Nilsen, 1971, 1978; Weitzman et al., 1972). Studies over the past three decades document a continued perpetuation of gender inequality in picture books; female characters are still underrepresented in Caldecott and popular books, more likely to be restricted to domestic and nurturing social roles and exhibiting disproportionately low levels of authority, competence and social status (Crisp \& Hiller, 2011a; Crisp \& Hiller, 2011b; Crisp \& Knezek, 2010; Hamilton et. al, 2006; Tsao, 2008).

In 2019, The Guardian Newspaper (Ferguson, 2019) published an in-depth analysis of the 100 bestselling children's books of 2018 in the UK. This study found little has changed in recent years with 1.6 books with male lead characters for every one book with female lead characters while male villains were seven times more likely to occur than female villains. Furthermore, female characters in bestselling books were far less likely to speak in the stories than male characters while $20 \%$ of the books contained no females at all. Twenty two per cent of the books in this study had been published in the previous 12 months and these continued the historical gender bias towards male characters with $59 \%$ of characters being male and $41 \%$ female. Additionally, only two of the top 100 books showed a main female character who was also from a black, Asian or minority ethnic (BAME) group. Moreover, no same sex families or relationships were presented in any of the books (Ferguson, 2019). These findings suggest when intersectionality or a combination of characteristics such as race and gender identity is considered, female characters from minority ethnic groups, as well as characters other than heteronormative gender identities and those who are both minority ethnic and gender diverse are even less likely to be represented in children's books.

\footnotetext{
1 Awarded annually by the Association for Library Service to Children (ALSC) to the artist of "the most distinguished American picture book for children”.
} 
This historical and continued gender imbalance in children's books is concerning given picture books are an important cultural mechanism for teaching gender roles to children (Crisp \& Hiller, 2011a; b; Crisp \& Knezek, 2010; Hamilton et. al, 2006; Anderson \& Hamilton, 2005; Peterson \& Lach, 1990; Tsao, 2008). Because books provide standards that define feminine and masculine behaviour, represent gender models for children (Peterson \& Lach, 1990; Taylor, 2003; Tsao, 2008) and can help children explore challenging social issues that may mirror real events in their lives, such as discrimination, cultural and racial bias and gender inequity, it is important to address and challenge the current gender imbalance in books when selecting and using books with young children. Given the central role of children's books in ECEC and the expectations of UN CRC and educational policies governing ECEC it is incumbent upon educators to consider and promote positive representations of gender identity.

Despite this importance, evidence suggests the book collections within many early childhood classrooms reflect a bias towards male leading characters. A study of book collections in 11 early childhood sites in Atlanta, Georgia (Crisp et al., 2016) reported books which contained leading characters, had $28.2 \%$ female leads compared to $53.5 \%$ with male leads, while the remaining $18.2 \%$ had lead characters referred to in second person without referring to gender, for example "the child". When considered with the evidence of gender bias in the most popular selling books, it appears adults who select books for children may unwittingly be exhibiting gender bias themselves when sourcing books for children. This is particularly important for those who care for and educate young children and stands at concerning odds with the requirements and expectations of educational policies rooted in the UN CRC.

\section{Categorising gender representation in children's books}

Studies of gender representation of children's books have traditionally focussed on the ratio of male to female leading characters following a binary and normative understanding of gender and gender nouns and pronouns (e.g. girl, woman, man, boy, he, she). A few studies have considered the nature of employment and social roles performed by characters, including positioning of characters in indoor or outdoor environments and activities as well as personality traits exhibited by the characters (Nilsen, 1971, 1978; Weitzman et al., 1972). Some studies have also considered levels of authority, competence, social status and the nature of relationships between characters (Crisp \& Hiller, 2011a, b; Crisp \& Knezek, 2010; Hamilton et. al, 2006).

While the majority of studies in this area have focussed on heteronormative interpretations of gender, a number of more recent studies have included consideration of gender identities outside of the traditional binary and normative understandings of research (Crisp et al., 2016; Daly, 2017; Kelly, 2012; Sullivan \& Urraro, 2017) Crisp et al. (2016) used categories of cisfemale/ciswoman, cismale/cisman, transwoman, transman, ungendered and other, though found no books in their study that were classified in the categories of transwoman or transman. Sullivan and Urraro (2017) when classifying books in their study of transgender representation in children's 
books used indicators including preferred pronouns and gender expression. Sullivan and Urraro's study focussed only on books containing one or more transgender characters and within their sample they identified four categories which they assigned as non-binary; gender creative; transgender and unspecified. Both Kelly (2012) and Daly (2017) included consideration of same sex and other gender-diverse family structures.

Consequently, it could be argued that investigating gender in children's books in the twenty-first century and especially in light of the UN CRC and associated educational polices currently governing ECEC, should include consideration of inclusive understandings of gender diversity rather than only traditional binary understandings of gender.

\section{This study}

This paper reports on a small cross-cultural study which investigated the nature of gender representation in picture books in eight early learning centres in Australia and the United States. The Australian data are drawn from a larger study which investigated the factors and relationships influencing the use of children's literature to support principles relating to cultural diversity in the kindergarten rooms of long day care centres (Adam, 2019). The US data are drawn from a smaller project which was conducted to draw comparable data on the component of the Australian study that focussed on which picture story books were shared with young children. This enabled this cross-cultural comparative study.

\section{Research question}

What is the nature of gender representation in the most commonly read picture books in early learning centres for 3-5-year-old children in Australia and the United States?

\section{Ethics}

This research was conducted with ethical approval granted through the Internal Review Board (IRB) and ethics processes of the authors' universities. Participants were given an information letter outlining the purpose of the research and their involvement. They were informed about confidentiality and security and their right to withdraw. All participants agreed to take part and signed a consent form.

\section{Study sites}

Childcare centres in the United States and Long Day Care centres (LDCs) in Western Australia provide full-time or part-time care for children aged birth to 5 years in purposefully built or adapted buildings. These facilities are owned and managed by non-profit organisations, local councils, community organisations, private operators and employers. All LDCs in Australia must be operated in accordance with 
the Education and Care Services National Law and Regulations (ACECQA, 2012). Childcare Centres in the United States must also be operated in accordance with state and federal laws and regulations. Many centres in the United States are credentialed by the National Association for the Education of Young Children (NAEYC) or the government funded Head Start program. Educational policies and requirements in both countries hold expectations of early childhood education and care to include consideration of gender and gender diversity within their programs. Typically, child centres in both countries have separate spaces, programs and curriculum for infants (birth-24 months), toddlers (24-36 months) and kindergarten (36 months-preschool age) children. Childcare centres in the United States separate preschool and kindergarten children into classrooms designated for 3 year olds, 4 year olds or 5 year olds. All ECEC classrooms in the United States must have at least one teacher with an early childhood teaching certificate. In Australia, long day care centres with more than 25 children have been required since 2012 to place at least one educator who holds an early childhood teaching degree in each classroom.

The study was conducted in the kindergarten rooms of four long day care centres in Western Australia and four early learning centres in eastern United States. While, as previously described, there are some differences in childcare contexts between Australia and the United States, childcare centres in both countries were selected for this study due to the importance of early exposure to positive gender role models as outlined earlier. In addition, educational policies and requirements in both countries, in line with the UN CRC and the mission statement of UNESCO, require ECEC to include consideration of gender and gender diversity within their programs. Furthermore, "schools and childcare settings may be the only venues where children can learn substantive information about the world and about worldviews beyond their own" (Boutte et al., 2008 p. 944). This is important to children's early development across all of the selected contexts.

Centres were selected by stratified purposeful sampling. Western Australian sampling was informed by data from the 2011 Australian Census (Australian Bureau of Statistics [ABS], 2011) in order to select regions of diverse demographics including different socio-economic profiles, varied ethnic population concentrations and urban and rural communities. The US centres were selected from government and privately funded non-profit centres with which the researcher had an existing research relationship, with consideration given to those centres which provided services to children and families from diverse cultural backgrounds and operated under policies incorporating inclusion and respect for diversity. Stratified purposeful sampling is particularly useful to study different models of implementing a particular teaching and learning strategy (Suri, 2011), in this case, book sharing with young children.

\section{Research participants}

In Australia, 24 educators with qualifications ranging from an Education Assistant Diploma to a Bachelor of Education degree agreed to be part of the study. Educators recruited included each centre coordinator and the educators in the kindergarten rooms of the centre. 
In the USA study 20 educators agreed take part in the research with qualifications ranging from a high school degree to a Bachelor of Arts in Education degree. Educators recruited included each centre coordinator and the early childhood educators in the rooms designed for preschool and kindergarten children.

Within this study, the children in the participating Australian kindergarten rooms also participated. The parents of the children were invited to give informed consent for observation of children's participation in book sharing and use. The children in the Australian centres were informed of the researcher's presence and the researcher spent time in each centre prior to the formal observations, during which she invited the children to handle and observe the cameras to be used.

The children in the USA centres did not participate in this study as data collection only related to the books shared by the teachers. There were 110 child participants in the Australian study, while the USA centres involved in this study served 161 children. The centres and all participants were assigned pseudonyms to ensure anonymity. For the purposes of this study the centres are identified as AUS 1-4 and USA 1-4. Furthermore, observational data relating to the books shared by educators with children were analysed and described.

\section{Methods}

Conceptually, this study is framed within a critical pedagogical perspective (Boutte et al., 2008; Freire, 1972, 2000). Implicit in this conceptualisation is a probe into how literacy and literature in education "mediates messages that children receive about their (cultures and) roles in society" (Boutte et al., 2008, p. 943). Within this perspective, a critical discourse analytic methodology was employed to analyse both the text and images in the books. In critical discourse analysis "an understanding of what is normatively questionable in our societies and of the desirable direction for improvement precedes the analysis" (Nonhoff, 2017 p. 3). Given the evidence outlined in the literature review of this paper of the dominant normative understanding of gender and gender roles in our society, a critical discourse analysis approach to this study aimed to "analyse in particular those discourses that express, legitimate, reproduce or question relations of power and domination" (Nonhoff, 2017 p. 3).

\section{Book audit}

An audit was conducted of all children's books available for use in each participating room in both studies. A software program called Book Collector was used in conjunction with an ISBN scanning app called CLZ Barry on an iPhone 5 to record the publishing details of the books. The software package is designed as a commercial package for consumers to record publication details of book collections.

\section{Book sharing observation data}

In the Australian study, video recorded observations were taken of every book sharing session for a period of five consecutive weekdays in each centre. For this paper, 
the publication details of the picture story books selected for use during the study as well as the amount of time each book was used over the observation period, were extracted from the observation data. Where a book was shared multiple times the total time for the book was recorded.

In the US study, observations and video recording were not possible due to operational constraints so educators were asked to record the title and author of each picture story book they shared with children over a consecutive 5-day period and also to note how much time was spent sharing each book. Where a book was shared multiple times the total time for the book was recorded.

For this paper, the 12 most read picture story books shared in each of the participant centres over the 5-day observation period were selected for reporting. The rationale for this sample was due to initial analysis of the four Australian centres showing over a 5-day observation period of $6 \mathrm{~h}$ per day in each centre a total of 186 picture story books shared by educators. However, in each of the four centres, the amount of time spent on some books far outweighed that spent on others. Therefore, the books were ranked by the amount of time educators spent sharing them with children across each observation period. Initially it was planned to select the top ten books from each centre (21.5\% sample size); however, in two of the four centres, the 10th highest length of time was recorded for 3 books. Consequently, it was decided to select the top 12 ranked books for each centre resulting in a sample size of $25 \%$ of all books shared.

The USA study sought to draw comparable data with the Australian study, so it also used the sample of the 12 most frequently read books in each centre, resulting in a sample size of 96 books. Of the 96 books, there were three titles that appeared twice. Two titles appeared in both one Australian centre and one USA centre, while one book appeared in two of the USA centres. These books were counted as separate books for data analysis and reporting to ensure results accurately reflected the nature of books shared most often in each participant centre.

\section{Harper's framework of gender stereotypes in children's literature}

\section{Development}

Drawing on the work of those in the field of anti-bias curriculum (Derman-Sparks, 1989; Davis, 1984; NAEYC Position Statement, 2002) and her own previously published research on categorising multicultural children's literature (Harper \& Brand, 2010). Harper developed a framework to assist in the categorisation of children's books that would consider the nature of the underlying messages picture books may promote.

While other researchers, as outlined earlier, used approaches such as calculating the percentages of representation of males, females and gender-diverse characters; number of speaking roles for gendered characters; and gendered behaviours, Harper sought to consider the overt and covert messages of books in relation to gender and gender activities and roles. Adhering to the critical pedagogical framework of this study, this process went beyond the proportion 
of representation of different genders to examine those discourses that express, legitimate, reproduce or question (Nonhoff, 2017) normative "assumptions about traits, behaviors and roles that people in the labeled [gender] categories are thought to possess" (Kite et al., 2008, p. 206). These portrayals include, though are not limited to, images of physical appearance, descriptions of personality traits, and activities and roles performed by characters in the story. Examples include females being described or portrayed as beautiful, graceful, artistic or homely; nurturing, passive and dependent, and males being portrayed as powerful, clever, assertive, handsome, independent and accomplished (Crisp \& Hiller, 2011a, b, Crisp and Knezek, 2010; Davies, 1989; Kite et al., 2008; Seitz et al., 2020; Taylor, 2003).

To conduct critical discourse analysis of content in children's books, Harper considered the following six story characteristics. While there is some overlap between some of these characteristics, by considering each a comprehensive critical analysis of books and their overt and covert messages could be achieved.

1. Language and details relating to gender and gender roles:

For example, use of gender specific or neutral names, pronouns or labels; language relating to characters' roles, descriptions and images of physical appearance; occupations (such as postman) and personality traits.

2. Illustrations:

For example, the clothing worn by characters, their physical location or positioning within the book page layout; activities in which characters are engaged; and the relationship of characters to each other.

3. Emotions, attitudes and needs of characters:

For example, female characters are portrayed as passive, weak, emotional and needing assistance of males to solve problems, while male characters are outgoing, strong and competent vs. the representation of universal human emotions and needs.

4. Experiences, achievements and values:

For example, the portrayal of normative "typical" gendered achievements and values such as a strong boy winning a football game while passive girls cheer for the boy.

5. Activities, roles and relationships of characters:

For example, the portrayal of a nuclear family with the mother featured in the home, cooking and cleaning, and caring for the children while the father is reading the newspaper, conducting maintenance on the car or going to work.

6. Story content maintains, reinforces, challenges or disrupts gender boundaries and stereotypes:

For example, the storyline reinforces, maintains, challenges, or disrupts heteronormative representations of masculinity and femininity.

Harper initially developed these story characteristics into three categories (Appendix 1) and are summarised as follows: 
1. Gender Stereotypical (Traditional) — these books maintain traditional gender boundaries and reinforce gender stereotypes.

2. Gender Sensitive (Non-traditional) - these books limit gender stereotypes and may cross rigid traditional gender boundaries and provide positive role models that allow children to see a range of possibilities in their future.

3. Gender Neutral (Ungendered) — these books open possibilities for readers' interpretation and increase readers' exposure and awareness of gender possibilities.

\section{Coding trials}

During development of the categories Harper trialled the framework with a sample of 100 books. The majority of books could be coded to specific categories quite easily as each met indicators in only one of the three categories.

\section{Revisions}

During the coding trials, a small number of books appeared to promote the possibility of diverse gender roles but also contained inconsistencies within the storyline, often occurring near the end of the story, which revert back to traditional behaviours or values, thus, maintaining traditional gender boundaries which reinforce gender stereotypes.

These books contained elements across both Gender-Stereotypical and GenderSensitive categories. For example, one book that largely focussed on the story of a young girl challenging gender stereotypes in a playground game, finished with the lead character deferring to a male character when a problem arose during the game. Thus, while this book promoted female agency for most of the storyline, it concluded with the underlying message of a male character solving the problem and "saving the day".

Through this analysis a fourth category was created to identify such books. Additionally, a notes section was added to the framework so key points, inconsistencies or contentious issues which might occur during the book analysis and coding process could be highlighted. This enabled a more nuanced analysis of storylines and avoided the likelihood of a story being classified into a category on the basis of one feature. The fourth category is summarised as follows:

Gender Restrictive (Traditional and Non-traditional)_books that create an awareness of the possibilities of diverse gender roles but ultimately revert back to traditional gendered behaviours or values, thus, maintaining traditional gender boundaries and reinforcing gender stereotypes.

The revised Harper's Framework of Gender Stereotypes in Children's Literature (Harper, 2016d) is provided as Appendix 2.

\section{Peer review}

Harper presented an initial draft to, and invited feedback from, academics in Australia and in the United States at research symposiums (Harper, 2016a, b, c). Adam participated in the Australian symposiums. These symposiums included workshop 
opportunities for in-service and pre-service teachers, faculty and other educators to trial the use of the framework on a further sample of books, thus, providing additional validity to (Harper's Framework of Gender Stereotypes in Children's Literature (Harper, 2016d).

The framework and the interim results from this study were presented in an unpublished conference paper at the 2018 Hawaii International Conference on Education (Harper \& Adam, 2018). Feedback from conference delegates indicated strong support for the application and credibility of the framework. The authors saw the current study as a significant and unique opportunity to investigate the nature of gender portrayal in children's literature.

\section{Data analysis}

Hard copies of the 96 books were obtained for analyses by the researchers. First, the two researchers independently coded $10 \%$ of the books $(\mathrm{N}=10)$ books. In analysing the books, each researcher followed the following steps. (1) Each book was read in its entirety within an agreed timeframe. (2) Using Harper's Framework of Gender Stereotypes in Children's Literature, each book was re-read (sometimes multiple readings were conducted) and coded against indicators on the framework while notes were simultaneously recorded. (3) Researchers then held an interrater reliability conference resulting in $100 \%$ agreement. (4) The rest of the sample was then randomly assigned to each of the researchers to complete the remaining analysis following the steps outlined above. (5) The analysis was recorded in an Excel spreadsheet with fields representing the participating country, centre or school, book title, author, gender category and notes.

\section{Results}

\section{Examples of each category of book}

This section provides vignettes of salient features of one book typical of each category. Detailed coding can be found in Appendices 3, 4, 5, 6 .

\section{Gender-stereotypical category example text-Harry the dirty dog}

This book follows the adventures of the central character; a dog called Harry. The illustrations show bias towards male representation and stereotypes of men. There are over 24 men portrayed in stereotypical roles including road workers, railway workers, shop owner, construction workers, window cleaners, maîtres de and mechanics. There are only seven adult females portrayed. Only one of these represents a female working outside the home-playing the role of a shop assistant. The other adult females are portrayed as shopping, caring for or accompanying children, dining with men and performing household chores. The number of children in images is evenly split between boys and girls. However, boys are more often 
represented in active roles such as walking a dog, whereas girls are mostly portrayed passively. The two main children in the story are consistently presented with the boy taking a more active role such as scrubbing and brushing the dog, and the girl performing more nurturing, domestic roles such as patting the dog and carrying towels.

\section{Gender-restrictive category example text-I want to be a police officer}

The use of the gender-neutral term officer and the inclusion of female police officers imply an intention of promoting gender-neutral or inclusive occupational opportunities. However, a bias towards males and male stereotypes in the illustrations contradicts this implication. Males outnumber females 15:3. Furthermore, the male officers are featured on pages alongside or using equipment, horses, bicycles, motorcycles, aircraft, boats, police cars, vehicle inspections and a ranger tower. In contrast, the three females are depicted in passive and "friendly" roles. These include one female pictured on the cover smiling but with no obvious duties or activities. Another female is pictured talking and smiling with two female citizens with the accompanying text stating, "Police are able to do their job better when they make friends with the people in the neighborhood". The third female is pictured on a double page spread about police dogs. On one page a male officer on active duty is featured with his dog, while on the opposite page is a female officer is smiling at and patting her dog with the accompanying text stating, "The dogs and their partners work hard. But great friends make a great team". This portrayal of females as passive and emotional contrasts sharply to the male officers in active duty.

\section{Gender Sensitive Category Example text - Clothesline Clues}

This book uses gender neutral terms such as firefighter and mail carrier, females outnumber males by one, females are portrayed in occupations traditionally considered to be male roles: mail carrier, firefighter, astronaut and carpenter. Males are portrayed in roles such as an artist, that generally could be performed by either gender and others that are more traditional such as farmer and chef.. Thus, the book crosses some traditional gender boundaries and promotes mostly gender-neutral achievements, though, the researchers noted there were no males depicted in what might be considered traditional female roles.

\section{Gender-neutral category example text-Not a box}

This book depicts an ungendered rabbit playing with a box while imagining a multitude of scenarios including firefighting, racing car driving, hot air ballooning and space travel. Each scenario contains activities, roles and occupations which exhibit universal notions of childhood play and imagination. The book is dedicated "To children everywhere sitting in cardboard boxes". This book leaves the reader open to interpretations that could complicate or disrupt traditional depictions of masculinity and femininity through an ungendered character. 


\section{Gender Categories of Books in Cross Cultural Study}

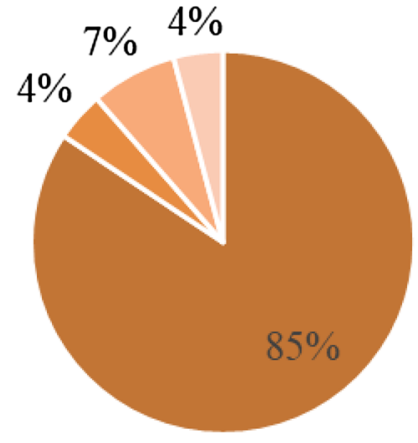

- Gender Traditional $\square$ Gender Restrictive

$\square$ Gender Sensitive $\quad$ Gender Neutral

Fig. 1 Gender categories of books in cross-cultural study

\section{Distribution of Gender Categories by Country}

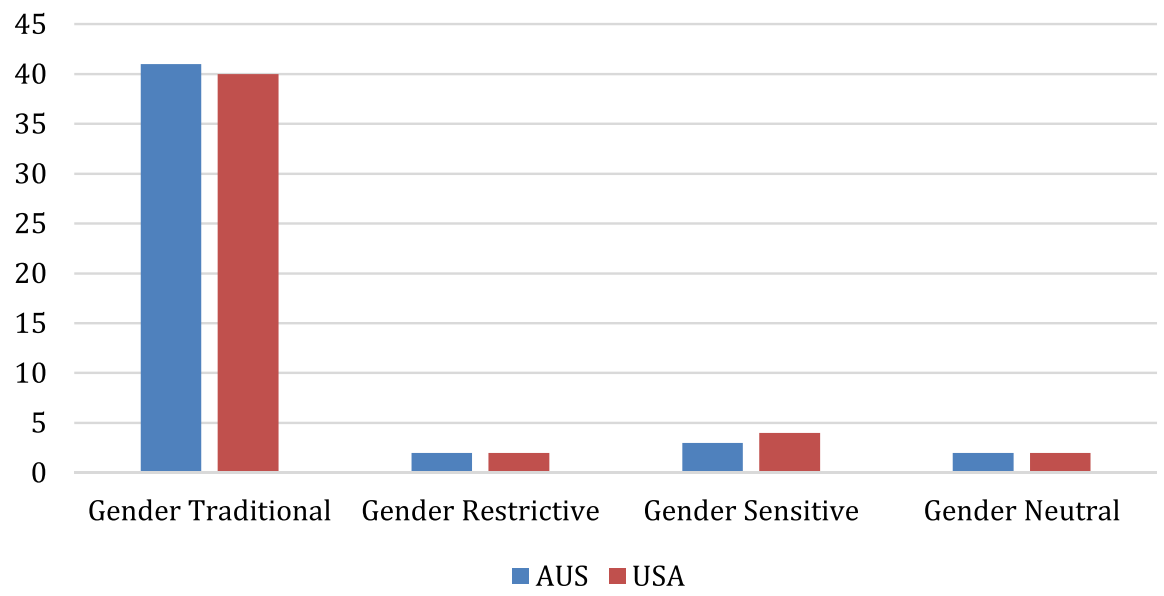

Fig. 2 Distribution of gender categories by country

The majority of books $(\mathrm{N}=81)$ across all centres in both countries shared by educators in this study reflected traditional, binary and stereotypical viewpoints of gender and gender roles, thus, affirming traditional gender stereotypes. 


\begin{tabular}{|l|l|l|l|l|l|l|l|l|l|}
\hline \multicolumn{7}{|c|}{ Distribution of Categories of Books Across the Rooms in the Study } \\
\hline \multicolumn{3}{|c|}{ AUS Centres and Books } & \multicolumn{5}{c|}{ USA Centres and Books } \\
\hline & GT & GR & GS & GN & & GT & GR & GS & GN \\
\hline AUS 1 & 9 & 0 & 2 & 1 & USA 1 & 10 & 0 & 1 & 1 \\
\hline AUS2 & 9 & 1 & 1 & 1 & USA 2 & 9 & 0 & 2 & 1 \\
\hline AUS 3 & 12 & 0 & 0 & 0 & USA 3 & 9 & 2 & 1 & 0 \\
\hline AUS 4 & 11 & 1 & 0 & 0 & USA 4 & 12 & 0 & 0 & 0 \\
\hline TOTALS & $\mathbf{4 1}$ & $\mathbf{2}$ & $\mathbf{3}$ & $\mathbf{2}$ & TOTALS & $\mathbf{4 0}$ & $\mathbf{2}$ & $\mathbf{4}$ & $\mathbf{2}$ \\
\hline
\end{tabular}

Fig. 3 Distribution of categories of books across the rooms in the study

\section{Distribution of the categories}

Eighty-one of the books were categorised as Gender Traditional, four books were categorised as Gender Restrictive; seven were categorised as Gender Sensitive and four were categorised as Gender Neutral. Figure 1 shows these results by percentages.

Furthermore, while intersectionality was not the focus of this study, the authors noted that none of the books in the study showed overt portrayal of transgender characters or gender diversity other than normative binary definitions of gender.

\section{Comparing the contexts}

The distribution in the categories was strikingly similar between the two countries with a difference of only one book in two of the categories as shown in Fig. 2.

Additionally, the distribution of books was similar across the eight participating classrooms. This distribution is shown in Fig. 3. All centres had at least nine books that were gender stereotypical and no more than two books in any of the other categories. Three centres, two in Australia and one in the United States, did not use any books among their top 12 from the gender-sensitive or neutral categories that may assist in promoting gender diversity or equity.

\section{Discussion}

In line with the critical pedagogical perspective of this study, the critical discourse analysis undertaken through the use of Harper's Framework of Gender Stereotypes in Children's Literature allowed for a unique insight into the overt and covert messages about gender and gender roles portrayed in children's books. As shown in Fig. 3 the similarities of findings within and between the two countries were remarkable.

All participant centres were guided by policies rooted in the UN CRC and, thus, were explicitly required to consider and address issues of gender and gender identity as part of their curriculum, resources and instructional practice. However, the overwhelming majority of books $(\mathrm{N}=81)$ shared by educators in this study promoted traditional, binary and stereotypical viewpoints of gender and gender roles. 
Another four books portrayed some messages of gender equity. However, these were contradicted by the overall storylines or conclusions which reverted to traditional stereotypical gendered behaviours or values. Furthermore, as shown in the vignettes of typical books, many of these messages were conveyed implicitly through illustrations and positioning of characters in particular roles, rather than explicitly in the text. This is concerning because illustrations attract more visual attention than print; beginning and emergent readers initially focus on book illustrations, not text to gain meaning (Justice et al., 2008; Mol \& Bus, 2011). Thus, illustrations are very important to young children as they use their working memory capacity to "interpret illustrations and link the story content with the illustrations" (Mol \& Bus, 2011).

These findings show challenges identified in studies such as Chick's (2002) are more widespread and cross-cultural within the United States. Australia faces similar challenges in book selection for book sharing in early education settings. Moreover, these findings are concerning as evidence shows gender development is a critical part of the earliest and most important learning experience of young children (Davies, 1989; Narahara, 1998; Peterson \& Lach, 1990) and book characters provide role models and implicit definitions of masculinity and femininity for children (Crisp \& Hiller, 2011a, b. Crisp \& Knezek, 2010; Davies, 1989; Taylor, 2003). Thus, the content and illustrations contained in children's literature have a long-term influence on children's gender development because they communicate cultural and social norms to children.

In addition, children's own biases can be increased through portrayal of gender bias in picture books and sexist instructional materials (McCabe et al., 2011; Poarch \& Monk-Turner, 2001; Rawson \& McCool, 2014). McCabe and colleagues argue "children's books reinforce, legitimate, and reproduce a patriarchal gender system" (2011, p198). The cumulative effect of this can lower girls' self-esteem as well as their occupational aspirations (Caldwell \& Wilbraham, 2018). Moreover, boys can develop a sense of entitlement (Tognoli, et al., 1994); and children can be led to believe girls are less worthy than boys (Poarch \& Monk-Turner, 2001; Rawson \& McCool, 2014). Thus, the children in this study are at risk of developing similar attitudes about their own gender identity and roles in society.

A small number of the books $(\mathrm{N}=7)$ portrayed gender-sensitive storylines in which characters could be positive role models that allow children to see a range of possibilities in their future. Another four books had no gendered characters and these books may open possibilities for the reader's interpretation and increase readers' exposure and awareness of gender possibilities.

While this inclusion of some non-traditional books may give some cause for optimism, this must be tempered with caution, given they were few compared to those promoting rigid gender stereotypes. Furthermore, while intersectionality was not the focus of this study, similar to the findings of Crisp et al., (2016) the authors noted none of the books in the study showed overt portrayal of transgender characters or gender diversity other than normative binary definitions of gender. Hence, while through these few books children might see male and female characters in non-traditional occupations or exhibiting personality traits traditionally portrayed through rigid gender stereotypes, these were aligned with binary characters or ungendered 
characters such as animals, or children described as "the child". This could contribute to children from families with gender-diverse members developing a sense of exclusion or difference while reaffirming a notion of being "normal" to children from traditional cisgender families (Naidoo, 2012).

The larger study from which the Australian data for this study was drawn found 99\% of books shared with children in the Australian centres promoted monocultural, dominant culture viewpoints and ideologies (Adam 2019; Adam \& Barratt-Pugh, 2020) and children in that study who were from minority ethnic backgrounds were unlikely to see themselves reflected in the books used in their education setting, contributing to an invisibility or marginalisation of these children in the curriculum (Adam, 2019; Adam \& Barratt-Pugh, 2020). Therefore, it could be argued that girls in the participating centres of this study who were also from minority ethnic backgrounds would be even less likely to see reflections of themselves or their own backgrounds, consequently contributing to further invisibility and marginalisation.

Within the US classrooms, more multicultural books were accessible to children. However, the majority of the US educators noted these were mostly "in storage, because they were used at precise times throughout the year which coincided with holidays, festivals, and events". Similar to the Australian study, this suggests limited understanding and a tokenistic approach to the use of multicultural literature largely focussed on a notion of "special" celebrations and festivals (Adam, 2021; Adam \& Barratt-Pugh, 2020). Thus, girls from minority group backgrounds in the US centres, as with the Australian centres, may be at risk of further marginalisation, while the goals and requirements of the UN CRC and educational policy are at further risk of not being met.

\section{Conclusion}

Given the expectations of the UN CRC and the guiding policies under which the participant centres operate, it is incumbent upon the educators to consider matters of gender equity in their curriculum, resources and pedagogical approaches. The books educators choose to read aloud send powerful messages that may influence children's identity, perpetuate gender stereotypes or break down gender barriers and the findings of this study suggests a significant oversight in the book selection practice of these educators. The books in this study overwhelmingly contribute to the perpetuation of gender stereotypes rather than promote children's identities and rights to participate in the community and larger society regardless of gender or gender identity.

Given the current gender imbalance and portrayal of gender stereotypes in many children's books, including those in this study, it is impractical to try and exclude or eliminate all children's literature containing stereotypes. Importantly, many of these same books are still high quality literature with strong storylines and good use of language and literary devices which portray other positive messages for children. However, through the pedagogical use of a critical lens, to support children to engage critically with this material and to carefully evaluate books to identify 
stereotypes through such tools as Harper's Framework for Classifying Gender Stereotypes in Children's Literature, educators can support children's developing identities and empower them to see the possibilities and to follow their interests, passions and dreams (Aina \& Cameron, 2011; Davies, 1989; Tsao, 2008).

It is hoped this study will support educators to apply a critical lens to evaluate gender stereotypes in books they select to share with children. Educators who include and share books that authentically and respectfully portray genderdiverse children and families, "could make a significant and positive contribution in normalising diverse representations of gender and sexuality on the pathway to rights realisation" (Gillett-Swan \& van Leent, 2019, p260). Children's gender attitudes may be positively affected through the sharing of appropriate children's literature (Aina \& Cameron, 2011; Tsao, 2008). Literature that emphasises gender-neutral language; depicts females and males engaged in a wide variety of activities, roles and relationships can promote gender equitable messages, demonstrate gender-neutral achievements and provide positive role models that allow children to see a range of possibilities in their future and avoid imparting the message that only certain people have agency and leadership qualities. Such actions will assist in developing a more inclusive and equitable society and support educators in achieving the requirements and goals of the UN $\mathrm{CRC}$ that are enshrined in national and educational policies.

Furthermore, it is hoped this study will encourage those involved in the care and education of young children to add their voices to the calls for authors, illustrators and publishers to include the full range of diverse characters in children's books.

Unique to this study is the use of Harper's Framework of Gender Stereotypes in Children's Literature (Harper, 2016d) which provides a new approach to analysing the nature of gender portrayal in children's books. This framework could be a useful tool to guide educators in applying a critical lens to books intended for children's use and for books within their own book collections. It may assist educators to address the expectations of policies relating to gender diversity and inclusivity. This framework could also be helpful to others who may want to conduct similar research.

\section{Limitations and recommendations}

The relatively small size of the sample (four centres in each country) necessarily limits the generalisability of the findings. So too, do the differences in the nature of early education and care in the United States and Australia, particularly with Australia having national policies, guidelines and frameworks and the United States having greater variance between states and jurisdictions. However, this has been mitigated somewhat by selection of participant centres that were guided by policies including expectations of considering and addressing gender equity. Furthermore, while the Australian data could be verified through the video analysis, the US data relied on self-reporting so it could be argued this may have resulted in a level of difference in objectivity and, thus, comparability of the data sources. It could be argued, however, the rigour of the study allows for implications to be relevant to similar contexts. Further studies could take the research 
into different educational contexts, including community and school based kindergartens as well as other early learning environments such as early childhood classrooms in primary schools. Such studies could also make comparisons between different centre operating structures, jurisdictions and governance requirements. Future studies could also examine the practice of educators when sharing books with children.

Further research is needed into the representation of gender identities outside of the traditional binary and normative understandings. This should consider both gender-diverse children and gender-diverse families. Such research could also include investigating intersectionality more rigorously by broadening the scope of the analysis to include the full nature of the diversity existing within the greater society.

\section{Appendix 1: Initial Framework of Gender Stereotypes in Children's Literature}

\begin{tabular}{|c|c|}
\hline Categories & Criterion \\
\hline Gender stereotypical (Traditional) & $\begin{array}{l}\text { - Incorporate language and details that define the traditional female } \\
\text { and male characteristics of a particular gender and or ethnicity } \\
\text { - Illustrations portray characters in gendered stereotypical ways } \\
\text { - Characters exhibit traditional gendered emotions, attitudes, needs } \\
\text { and experiences } \\
\text { - Characters demonstrate typical gender achievements and values } \\
\text { - Depict females and males engaged in activities, and roles and } \\
\text { relationships that mirror rigid "traditional gender boundaries" } \\
\text { - Maintain traditional gender boundaries and reinforce gender } \\
\text { stereotypes }\end{array}$ \\
\hline Gender sensitive (Non-Traditional) & $\begin{array}{l}\text { - Contains gender-sensitive language and labels } \\
\text { - Characters exhibit universal human emotions, attitudes, needsand } \\
\text { experiences } \\
\text { - Characters celebrate themselves as equal members of the human } \\
\text { race } \\
\text { - Story features characters that re-define traditional gender roles, } \\
\text { achievements and values } \\
\text { - Depict females and males engaged in a wide variety of activities, } \\
\text { roles and relationships that promote gender-neutral achievements } \\
\text { - Limit gender stereotypes, may cross rigid traditional gender } \\
\text { boundaries and provide positive role models that allow children to } \\
\text { see a range of possibilities in their future }\end{array}$ \\
\hline Gender neutral (Ungendered) & $\begin{array}{l}\text { - Emphasises gender-neutral language } \\
\text { - Characters exhibit universal human emotions, attitudes, needs and } \\
\text { experiences } \\
\text { - Characters demonstrate non-traditional gender values and accom- } \\
\text { plishments } \\
\text { - Depict females and males constructed with traits and engaged } \\
\text { in a variety of activities, roles and relationships that complicate } \\
\text { traditional depictions of gender and disrupt previous representa- } \\
\text { tions of masculinity and femininity } \\
\text { - Open possibilities for readers' interpretation and increase read- } \\
\text { ers' exposure and awareness of gender possibilities }\end{array}$ \\
\hline
\end{tabular}




\section{Appendix 2: Harper's Framework of gender stereotypes in children's literature}

\begin{tabular}{|c|c|}
\hline Categories & Criterion \\
\hline Gender stereotypical (Traditional) & $\begin{array}{l}\text { - Incorporate language and details that define the traditional female } \\
\text { and male characteristics of a particular gender and or ethnicity } \\
\text { - Illustrations portray characters in gendered stereotypical ways } \\
\text { - Characters exhibit traditional gendered emotions, attitudes, needs } \\
\text { and experiences } \\
\text { - Characters demonstrate typical gender achievements and values } \\
\text { - Depict females and males engaged in activities, and roles and } \\
\text { relationships that mirror rigid "traditional gender boundaries" } \\
\text { - Maintain traditional gender boundaries and reinforce gender } \\
\text { stereotypes }\end{array}$ \\
\hline $\begin{array}{l}\text { Gender restrictive (Traditional } \\
\text { and non-traditional) }\end{array}$ & $\begin{array}{l}\text { - May contain gender-neutral language (mailperson, not mailman) } \\
\text { - Characters exhibit universal human emotions, attitudes, needs and } \\
\text { experiences } \\
\text { - Depict females and males engaged in a wide variety of activities, } \\
\text { roles and relationships that may cross rigid traditional gender } \\
\text { boundaries } \\
\text { - Story initially features characters that re-define traditional gender } \\
\text { roles, achievements and values } \\
\text { - Story strives for gender equity but is contradicted by the overall } \\
\text { storyline or conclusion which reverts back to traditional stereotypi- } \\
\text { cal gendered behaviours or values } \\
\text { - Limits gender stereotypes; creates an awareness of the possibilities } \\
\text { of gender }\end{array}$ \\
\hline Gender sensitive (Non-traditional) & $\begin{array}{l}\text { - Contains gender-sensitive language and labels } \\
\text { - Characters exhibit universal human emotions, attitudes, needs and } \\
\text { experiences } \\
\text { - Characters celebrate themselves as equal members of the human } \\
\text { race } \\
\text { - Story features characters that re-define traditional gender roles, } \\
\text { achievements and values } \\
\text { - Depict females and males engaged in a wide variety of activities, } \\
\text { roles and relationships that promote gender-neutral achievements } \\
\text { - Limit gender stereotypes, may cross rigid traditional gender } \\
\text { boundaries and provide positive role models that allow children to } \\
\text { see a range of possibilities in their future }\end{array}$ \\
\hline Gender neutral (Ungendered) & $\begin{array}{l}\text { - Emphasises gender-neutral language } \\
\text { - Characters exhibit universal human emotions, attitudes, needs and } \\
\text { experiences } \\
\text { - Characters demonstrate non-traditional gender values and accom- } \\
\text { plishments } \\
\text { - Depict females and males constructed with traits and engaged in a } \\
\text { variety of activities, roles and relationships that complicate tradi- } \\
\text { tional depictions of gender and disrupt previous representations of } \\
\text { masculinity and femininity } \\
\text { - Open possibilities for readers' interpretation and increase read- } \\
\text { ers' exposure and awareness of gender possibilities }\end{array}$ \\
\hline
\end{tabular}




\section{Appendix 3: Coding example: gender traditional/stereotypical- Harry the dirty dog by Gene Zion}

\begin{tabular}{ll}
\hline Harper's Framework of gender stereotypes in children's literature \\
\hline Categories & Criterion Noted for this book \\
\hline Gender stereotypical (Traditional) & • Incorporate language and details that define the traditional female \\
and male characteristics of a particular gender and or ethnicity \\
- Illustrations portray characters in gendered stereotypical ways \\
- Characters exhibit traditional gendered emotions, attitudes, needs \\
and experiences \\
• Characters demonstrate typical gender achievements and values \\
• Depict females and males engaged in activities, and roles and rela- \\
tionships that mirror rigid "traditional gender boundaries" \\
- Maintain traditional gender boundaries and reinforce gender \\
stereotypes \\
\end{tabular}

Gendered pronoun "he" for main character. No other pronouns for other characters other than "the family"

Nuclear family depicted with dress and activities implying homemaker domestic mother and businessman father.

Males outnumber females almost 4:1

Multiple illustrations of male adult characters (24+) as roadworkers, railway workers, shop owner, construction workers, window cleaner, maître de, mechanic,

Female adult characters (7) as shop assistants, shopping, caring for/accompanying children, dining with men and/or children, performing household chores.

\section{Appendix 4: Coding example: gender restrictive-I want to be a police officer by Dan Liebman}

\begin{tabular}{ll}
\hline Harper's framework of gender stereotypes in children's literature \\
\hline Categories & Criterion noted for this book \\
\hline Gender restrictive & $\bullet$ May contain gender-neutral language (mailperson, not mailman) \\
(Traditional and Non-traditional) & $\bullet$ Characters exhibit universal human emotions, attitudes, needs and \\
& experiences \\
$\bullet$ & Depict females and males engaged in a wide variety of activi- \\
& ties, roles and relationships that may cross rigid traditional gender \\
& boundaries \\
$\bullet$ & Story initially features characters that re-define traditional gender \\
& roles, achievements and values \\
$\bullet$ & Story strives for gender equity, but is contradicted by the overall \\
& storyline or conclusion which reverts back to traditional stereotypi- \\
& cal gendered behaviours or values \\
$\bullet$ & Limits gender stereotypes; creates an awareness of the possibilities \\
& of gender
\end{tabular}

Contains gender-neutral language, i.e. police officer, officers, ranger, harbour police 
Promotes both males and females in roles of police officers; however:

Males:

Male officers outnumber females 15:3

Males are featured on pages using equipment, horse, bicycles motorbikes, aircraft, boats, police cars, making records, vehicle inspections, ranger tower

Females:

one pictured on cover smiling but with no obvious duties or activities

one on page talking to and smiling with two female citizens-accompanying text "Police are able to do their job better when they make friends with the people in the neighborhood".

one on double page spread about police dogs - male on one side working with the dog, female on opposite page smiling at and patting her dog-accompanying text, "The dogs and their partners work hard. But great friends make a great team".

Overall, this picture book attempts to limit gender stereotypes and promote gender equity using gender-neutral language featuring female characters that re-define traditional male-dominated occupations (Police) and gender roles within the Police occupation to create an awareness of the possibilities for females. However, the book pictures overwhelming depict males actively engaged in traditional gendered behaviours traditionally associated with Police roles, activities and behaviours, while book pictures depict females in passive Police roles with affective demeanour. The message of gender equity to children is contradicted due to the overshadowing representation of males, roles and activities shown in pictures and text which revert back to gendered traditional behaviours and values.

\section{Appendix 5: Coding example: gender sensitive-Clothesline clues, by Heling and Hembrook}

Harper's framework of gender stereotypes in children's literature

\begin{tabular}{ll}
\hline Categories & Criterion noted for this book \\
\hline Gender Sensitive (Non-Traditional) & - Contains gender-sensitive language and labels \\
& - Characters exhibit universal human emotions, attitudes, needs and \\
& experiences \\
$\bullet$ & Characters celebrate themselves as equal members of the human \\
race & Story features characters that re-define traditional gender roles, \\
& achievements and values \\
$\bullet$ & Depict females and males engaged in a wide variety of activities, \\
& roles and relationships that promote gender-neutral achievements \\
$\bullet$ & Limit gender stereotypes, may cross rigid traditional gender \\
& boundaries and provide positive role models that allow children \\
& to see a range of possibilities in their future \\
\hline
\end{tabular}

Some gender-neutral languages - mail carrier, firefighter

4 Females, 3 males

Women portrayed in occupations traditionally considered to be male dominated-mail carrier, firefighter, astronaut, carpenter — crossing traditional gender boundaries

Men portrayed in roles that generally could be associated with male and females, i.e. artist and others more traditional-farmer, chef

Overall, the book promotes females and males engaged in a wide variety of activities, roles and relationships that promote gender-neutral achievements 


\section{Appendix 6: Coding example gender neutral-Not a box by Antoinette Portis}

\begin{tabular}{ll}
\hline Harper's Framework of gender stereotypes in children's literature \\
\hline Categories & Criterion noted for this book \\
\hline Gender Neutral & $\bullet$ Emphasises gender-neutral language \\
(Ungendered) & - Characters exhibit universal human emotions, attitudes, needs and experiences \\
& • Characters demonstrate non-traditional gender values and accomplishments \\
& - Depict females and males constructed with traits and engaged in a variety of activi- \\
& ties, roles and relationships that complicate traditional depictions of gender and \\
& disrupt previous representations of masculinity and femininity \\
& - Open possibilities for readers' interpretation and increase readers' exposure and \\
& awareness of gender possibilities
\end{tabular}

Contains one ungendered animal character which exhibits universal notions of play and imagination while playing with a box

The main character imagines a range of activities with the box-firefighting, racing car driving, hot air ballooning and space travel

The book foreword states, "To children everywhere sitting in cardboard boxes".

The ungendered main character combined with the book forward combined with the author's dedication offers children open interpretations for imagination and activities for all gender identities, which may disrupt traditional depictions of masculinity and femineity.

Acknowledgements Helen Adam acknowledges and expresses her gratitude to both Edith Cowan University and the Australian Government Department of Education and Training for the support of the Collaborative Research Network Fellowship awarded to support the doctoral study from which the Australian data from this paper was drawn. Helen Adam also acknowledges the support of her Doctoral Studies supervisors: Professor Caroline Barratt-Pugh, Dr Yvonne Haig and Dr Janet Hunter.

Open Access This article is licensed under a Creative Commons Attribution 4.0 International License, which permits use, sharing, adaptation, distribution and reproduction in any medium or format, as long as you give appropriate credit to the original author(s) and the source, provide a link to the Creative Commons licence, and indicate if changes were made. The images or other third party material in this article are included in the article's Creative Commons licence, unless indicated otherwise in a credit line to the material. If material is not included in the article's Creative Commons licence and your intended use is not permitted by statutory regulation or exceeds the permitted use, you will need to obtain permission directly from the copyright holder. To view a copy of this licence, visit http://creativecommons.org/licen ses/by/4.0/.

\section{References}

Adam, H. J. (2019). Cultural diversity and children's literature: Kindergarten educators' practices to support principles of cultural diversity through book sharing. https://ro.ecu.edu.au/theses/2245,

Adam, H. (2021). When authenticity goes missing: How monocultural children's literature is silencing the voicesand contributing to invisibility of children from minority backgrounds. Education Sciences, 11(1), 32. https://doi.org/10.3390/educsci11010032. https://www.mdpi.com/2227-7102/11/1/ 32/htm. Accessed 27 Sept 2021.

Adam, H., Barratt-Pugh, C., \& Haig, Y. (2017). Book collections in long day care: Do they reflect racial diversity? Australasian Journal of Early Childhood., 42(2), 88-96. 
Adam, H., Barratt-Pugh, C. \& Haig, Y. (2019). "Portray cultures other than ours": How children's literature is being used to support the diversity goals of the Australian early years learning framework. Australian educational researcher. https://rdcu.be/bhMgn. Accessed 20 Feb 2021.

Adam, H., \& Barratt-Pugh. (2020). The challenge of monoculturalism: What books are educators sharing with children and what messages do they send? Australian Educational Researcher. https://link. springer.com/article/10.1007\%2Fs13384-019-00350-2. Accessed 20 Feb 2021.

Aina, O. E., \& Cameron, P. A. (2011). Why does gender matter? Counteracting stereotypes with young children. Dimensions of Early Childhood, 39(3), 11-20.

Anderson, D. A., \& Hamilton, M. C. (2005). Gender Stereotyping of parents in children's picture books: The invisible father. Sex Roles, 52, 145-151.

Australian Bureau of Statistics. (2011). Community profiles. Australian Bureau of Statistics. http://www. abs.gov.au/websitedbs/censushome.nsf/home/communityprofiles?opendocument \&navpos=230. Accessed 13 Jan 2019.

Australian Children's Education and Care Quality Authority. (2012). Education and care services national law and regulations. https://www.acecqa.gov.au/nqf/national-law-regulations/nationalregulations. Accesse 13 Jan 2019.

Boutte, G. S., Hopkins, R., \& Waklatsi, T. (2008). Perspectives, voices, and worldviews in frequently read children's books. Early Education and Development, 19(6), 941-962.

Caldwell, E. F., \& Wilbraham, S. J. (2018). Hairdressing in space: Depiction of gender in science books for children. Journal of Science \& Popular Culture, 1(2), 101-118. https://doi.org/10.1386/jspc.1.2. 101_1

Chick, K. A. (2002). Challenging gender stereotypes through literature: Picture books with strong female characters. Journal of Children's Literature, 28(2), 19-24.

Chick, K. A., Heilman-Houser, R., \& Hunter, M. (2002). The impact of child care on gender role development and gender stereotypes. Early Childhood Education Journal, 29(3), 149-154.

Crisp, T., \& Hiller, B. (2011). "Is this a boy or a girl"? Rethinking sex-role representation in Caldecott medal-winning picturebooks. Children's Literature in Education. https://doi.org/10.1007/ s10583-011-9128-1

Crisp, T., \& Hiller, B. (2011). Telling tales about gender: A critical analysis of Caldecott medal-winning picturebooks, 1938-2011. Journal of Children's Literature, 37(2), 18-29.

Crisp, T., \& Knezek, S. (2010). "I just don't see myself here": Challenging conversations about LGBTQ adolescent literature. English Journal, 99(3), 76-79.

Crisp, T., Knezek, S. M., Quinn, M., Bingham, G. E., Girardeau, K., \& Starks, F. (2016). What's on our bookshelves? The diversity of children's literature in early childhood classroom libraries. Journal of Children's Literature, 42(2), 29-42.

Daly, N. (2017). Representations of diversity in the revised New Zealand picturebook collection. New Review of Children's Literature and Librarianship, 23(2), 172-186. https://doi.org/10.1080/13614 541.2017.1367583

Davies, B. (1989). Frogs and snails and feminist tales: Preschool children and gender. Allen \& Unwin.

de Groot Kim, S. (2011). Lessons learned early: Girls wait. In T. Jacobson (Ed.), Perspectives on gender in early childhood (pp. 231-246). Redleaf.

Derman-Sparks, L. (1989). Anti-bias curriculum: Tools for empowering young children. NAEYC.

Derman-Sparks, L., \& Edwards, J. O. (2010). Anti-bias education for young children and ourselves. NAEYC.

Diekman, A. B., \& Murnen, S. K. (2004). Learning to be little women and little men: The inequitable gender equality of nonsexist children's literature. Sex Roles, 50(5), 373-385. https://doi.org/10.1023/B:SERS. 0000018892.26527.ea

Ebach, J., Endepohls-Ulpe, M., Ikone, P., Rasinen, A., Virtanen, S., \& Zabern, J. S. (2009). Technology education for children in primary schools in Finland and Germany: Different school systems, similar problems and how to overcome them. Technology Des Education, 19, 367-379.

Estola, E. (2011). Discussing gender. In T. Jacobson (Ed.), Perspectives on gender in early childhood (pp. 39-58). Redleaf.

Ferguson, D. (2019). 'Highly concerning': Picture books bias worsens as female characters stay silent. The Guardian, 13. Needs the publishing date.

Fine, C. (2010). Delusions of gender: How our minds, society, and neurosexism create difference. Norton.

Freeman, N. (2007). Preschoolers' perceptions of gender-appropriate toys and their parent's beliefs about genderized behaviors: Miscommunication, mixed messages, or hidden truths? Early Childhood Education Journal, 34(5), 357-366.

Freire, P. (1972). Pedagogy of the oppressed. New York: Herder and Herder. 
Freire, P. (2000). Pedagogy of the oppressed. New York: Continuum.

Gee, B., \& Gee, J. (2005). Seeing learning in traditional classroom settings. Cromwell Press.

Gillett-Swan, J., \& van Leent, L. (2019). Exploring the intersections of the convention on the rights of the child general principles and diverse sexes, genders and sexualities in education. Social Sciences. https:// doi.org/10.3390/socsci8090260

Gollnick, D. M., \& Chinn, P. C. (2006). Multicultural education in a pluralistic society (8th ed.). Pearson.

Grau, S. L., \& Zotos, Y. C. (2016). Gender stereotypes in advertising: A review of current research. International Journal of Advertising, 35(5), 761-770. https://doi.org/10.1080/02650487.2016.1203556

Hamilton, M., Anderson, D., Broaddus, M., \& Young, K. (2006). Gender stereotyping and under-representation of female characters in 200 popular children's picturebooks: A twenty-first century update. Sex Roles, 55(11/12), 757-765.

Harper, L. J. (2016a). Selecting, evaluating \& embedding multicultural literature in the early childhood curriculum. Western Australia: School of Education, Edith Cowan University.

Harper, L. J. (2016b). The importance of evaluating children's literature for gender stereotypes. Western Australia: The Centre forResearch in Early Childhood, Edith Cowan University.

Harper, L. J. (2016c). Categorizing children's literature for gender stereotypes: Methodological considerations.Western Australia: Edith Cowan Institute for Education Research, Edith Cowan University.

Harper, L. J. (2016d). Unpublished work. Framework of gender stereotypes in children's literature.

Harper, L. J., \& Adam, H. (2018). Gender stereotypes in children's literature: A cross-cultural comparison. Hawaii, USA: The 16th Annual Hawaii International Conference on Education.

Harper, L. J., \& Brand, S. T. (2010). More alike than different: Promoting respect through multicultural books and literacy strategies. Childhood Education, 86(4), 224-233.

Jackson, S. (2007). "She might not have the right tools... and he does": children's sense-making of gender, work and abilities in early school readers. Gender and Education, 19(1), 61-77.

Justice, L. M., Pullen, P. C., \& Pence, K. (2008). Influence of verbal and nonverbal references to print on preschoolers' visual attention to print during storybook reading. Developmental Psychology, 44(3), 855-866. https://doi.org/10.1037/0012-1649.44.3.855

Kelly, J. (2012). Two daddy tigers and a baby tiger: Promoting understandings about same gender parented families using picture books. Early Years, 32(3), 288-288.

Kite, M. E., Deaux, K., \& Haines, E. L. (2008). Gender stereotypes. In F. L. Denmark \& M. A. Paludi (Eds.), Psychology of women: A handbook of issues and theories (pp. 205-236). Praeger.

Kortenhaus, C., \& Demarest, J. (1993). Gender role stereotyping in children's literature: An update. Sex Roles, 28(3/4), 219-232.

McCabe, J., Fairchild, E., Grauerholz, L., Pescosolido, B. A., \& Tope, D. (2011). Gender in twentieth-century children's books: Patterns of disparity in titles and central characters. Gender \& Society, 25(2), 197-226. https://doi.org/10.1177/0891243211398358

McNair, S., Kirova-Petrova, A., \& Bhargava, A. (2001). Computers and young children in the classroom: Strategies for minimizing gender bias. Early Childhood Education Journal, 29(1), 51-55.

Mendoza, J., \& Reese, D. (2001). Examining multicultural picture books for the early childhood classroom: Possibilities and pitfalls. Early Childhood Research and Practice, 3(2), 1-31.

Mol, S. E., \& Bus, A. G. (2011). To read or not to read: A meta-analysis of print exposure from infancy to early adulthood. Psychological Bulletin, 137(2), 267.

Morgan, H. (2009). Gender, racial and ethnic misrepresentation in children's books. A comparative look. Childhood Education, 85(3), 187-190.

NAEYC (National Association for the Education of Young Children) \& NAECS/SDE (National Association of EarlyChildhood Specialists in State Departments of Education). (2002). Early learning standards: Creating the conditions for success. Joint position statement. https://www.naeyc.org/ files/naeyc/file/positions/position_statement.pdf.Accessed 20 Feb 2021.

Naidoo, J. C. (2012). Rainbow family collections: Selecting and using children's books with lesbian, gay bisexual, transgender, and queer content. Libraries Unlimited, an imprint of ABC-CLIQ, LLC.

Narahara, M. M. (1998). Gender stereotypes in children's picture books (Project). University of California.

Nilsen, A. P. (1971). Women in children's literature. College English, 32, 918-926.

Nilsen, A. P. (1978). Five factors contributing to the unequal treatment of females in children's picture books. Top of the News, 34, 255-259.

Nonhoff, M. (2017). Discourse analysis as critique. Palgrave Communications. https://doi.org/10.1057/palco mms.2017.74

O’Neill, K. (2010). Once upon today: Teaching for social justice with postmodern picture books. Children's Literature in Education, 41, 40-51. 
Office of the High Commissioner for Human Rights. (1989). Office of the high commissioner for human rights.United Nations Human Rights. Retrieved from http://www.ohchr.org/EN/ProfessionalInterest/ Pages/CRC.aspx.

Peterson, S. B., \& Lach, M. A. (1990). Gender stereotypes in children's books: Their prevalence and influence on cognitive and affective development. Gender and Education, 2, 185-197.

Poarch, R., \& Monk-Turner, E. (2001). Gender roles in children's literature: A review of non-award-winning 'easy-to-read' books. Journal of Research in Childhood Education, 16(1), 70-76. https://doi.org/10. 1080/02568540109594975

Rawson, C. H., \& McCool, M. A. (2014). J Just like all the other humans? Analysing images of scientists in children's trade books'. School Science and Mathematics, 114(1), 10-18. https://doi.org/10.1111/ssm. 12046

Saltmarsh,. (2009). Becoming economic subjects: Agency, consumption and popular culture in early childhood. Discourse: Studies in the Cultural Politics of Education, 30(1), 47-59.

Seitz, M., Lenhart, J., \& Rübsam, N. (2020). The effects of gendered information in stories on preschool children's development of gender stereotypes. The British Journal of Developmental Psychology, 38(3), 363-390. https://doi.org/10.1111/bjdp.12323

Stromquist, N. P. (2013). Education policies for gender equity: Probing into State responses. Education Policy Analysis Archives, 21, 1-28.

Sullivan, A. L., \& Urraro, L. L. (2017). Missing persons' report! Where are the transgender characters in children's picture books? Occasional Paper Series, 2017(37), 4.

Suri, H. (2011). Purposeful sampling in qualitative research synthesis. Qualitative Research Journal, 11(2), 63-74.

Sylva, K., Siraj-Blatchford, I., \& Taggart, B. (2006). Assessing quality in the early years: Early childhood environment rating scale. Staffordshire: Trentham Books Limited.

Taylor, F. (2003). Content analysis and gender stereotypes in children's books. Teaching Sociology, 31(3), 300-311. https://doi.org/10.2307/3211327

Temple, C. A. M. M., Yokota, J., \& Naylor, A. (1998). Children's books in children's hands: An introduction to their literature. Boston: Allyn and Bacon.

Tognoli, J., Pullen, J., \& Lieber, J. (1994). The privilege of place: Domestic and work locations of characters in children's books. Children's Environments, 11(4), 272-280.

Tsao, Y. L. (2008). Gender issues in young children's literature. Reading Improvement, 45(3), 1-20.

UNESCO. (2016). Global education monitoring report. United Nations Educational, Scientific and Cultural Organization.

Weitzman, L., Eifler, D., Hokada, E. \& Ross, C. (1972). Sex role socialization in picturebooks for preschool children. American Journal of Sociology, 77(6), 1125-1150.

Publisher's Note Springer Nature remains neutral with regard to jurisdictional claims in published maps and institutional affiliations.

Helen Adam is a Senior Lecturer, Course Coordinator and researcher at Edith Cowan University. Helen's research addresses the role and importance of quality inclusive literature in the social and emotional and educational wellbeing of the child, with a particular focus on the importance of authentic representations and inclusion of cultural diversity in children's literature. Helen's work has a particular focus on promoting socially just and equitable education through the promotion of the publication and use of authentically diverse and inclusive literature as one way to break down barriers of prejudice and misunderstanding in society. Her work is published in internationally renowned research journals including Australian Educational Researcher and The Journal of Early Childhood Literacy.

Laurie J. Harper is an Associate Adjunct Professor at Edith Cowan University. She has worked on behalf of children, families and teachers over 25 years. As a teacher, she taught in primary schools for 12 years, at the University level, she has taught, supervised and mentored undergraduate and graduate students for 13 years. Her research focuses on children's literacy. Of particular interest is gender stereotypes and biases in cultural representations contained in children's literature, as well as access to authentically diverse and inclusive literature in the early childhood classroom. Laurie has presented her research at the state, regional, national and international levels. Her publications have appeared in peer-reviewed national 
journals such as Reading Improvement; Journal of Language and Literacy; Young Children: The Journal of the National Association for the Education of Young Children; and international journals; Childhood Education: The Journal of the Association for the Childhood Education International, Practical Literacy: The Journal of the Australian Literacy Educators' Association; and Early Childhood Education Journal. 